\title{
COMPLYING WITH THE SMOKING BAN BY STUDENTS BEFORE AND AFTER INTRODUCING LEGISLATIVE INTERVENTION
}

\author{
ADAM RZEŹNICKI ${ }^{1}$, IWONA STELMACH ${ }^{2}$, ALINA KOWALSKA ${ }^{1}$, JAN KRAKOWIAK ${ }^{1}$, \\ MICHAŁ ŻEBROWSKI ${ }^{1}$, and WŁODZIMIERZ STELMACH ${ }^{1}$ \\ ${ }^{1}$ Medical University of Lodz, Łódź, Poland \\ Department of Social and Preventive Medicine, Social Medicine Institute \\ ${ }^{2}$ Medical University of Lodz, Łódź, Poland \\ Copernicus Memorial Hospital, Department of Pediatrics and Allergy
}

\begin{abstract}
Objectives: More and more countries introduce a total ban on smoking tobacco in public places. The aim of this work was to evaluate the effectiveness of "The Act of 8 April 2010 on amendment of the act on protection of health against the consequences of consumption of tobacco and tobacco products and act on National Sanitary Inspectorate" and assess the frequency of complying with the smoking bans by the students of the Medical University of Lodz. Material and Methods: Between 2007-2011, at the Social Medicine Institute of the Medical University of Lodz, a study using random survey was carried out involving students who were starting their studies at the Health Department of the Medical University of Lodz. The analysis of the collected material showed that 1038 people reported being smokers at the time of the study. Among that group, 530 students were included in the study prior to, and 508 after the introduction of the amendment. In order to verify their compliance with the smoking ban, the respondents were asked whether they smoked only in designated areas or wherever they wanted to. Results: The ratio of people claiming they smoked anywhere they wanted to, disregarding the smoking ban, was $60 \%(\mathrm{~N}=318)$ and after the amendment had been introduced, this ratio was $62.2 \%(\mathrm{~N}=316)$, it increased by 2.2 percentage points. The observed difference was statistically irrelevant $\left(\mathrm{Chi}^{2}=0.530, \mathrm{p}>0.05\right)$. Conclusions: The Act "On amendment of the act on protection of health against the consequences of consumption of tobacco and tobacco products and Act on National Sanitary Inspectorate" in Poland did not result in the expected changes in the frequency of complying with the smoking ban by the 1st year students.
\end{abstract}

Key words:

Smoking ban, Smoking tobacco, Compliance with smoking ban, Students

\section{INTRODUCTION}

In recent years, frequency of tobacco smoking in Poland decreased, although age coefficients that are standardized as far as smoking among adults in Poland is concerned, are still among the highest in Europe [1,2]. On the basis of
Global Adult Tobacco Survey (GATS) that was carried out in Poland in 2009-2010 [3] it has become apparent that every 3 rd man (33.5\%, i.e., 5.2 million) and every 5 th woman (21\%, i.e., 3.5 million) at the age over 15 smoked every day. Occasional smoking was characteristic of a low percentage

The work was financed from the statutory funds of the Social Medicine Institute of the Medical University of Łódź, project No. 503/6-029-01/503-01. Project manager: Włodzimierz Stelmach, MD, PhD.

Received: March 28, 2014. Accepted: October 21, 2014.

Corresponding author: W. Stelmach, Medical University of Lodz, Department of Social and Preventive Medicine, Social Medicine Institute, Żeligowskiego 7/9, 90-752 Łódź, Poland (e-mail: alergol@kopernik.lodz.pl). 
of Poles $-3.3 \%$ men and $3.4 \%$ women. Despite the decreasing tendencies, 9.8 million Poles smoke every day or occasionally, which amounts to $30.3 \%$ of the population at the age of 15 and older [4].

In an attempt to help the world in its struggle with tobacco smoking epidemics and to protect millions of people against the risk of death from smoking related diseases, World Health Organization (WHO) has launched the MPOWER package. This tool is designed to support the Framework Convention on Tobacco Control (FCTC) - the 1st international treaty intended to fight tobacco worldwide [5]. The package includes 6 main and most effective strategies to combat tobacco: Monitor, Protect, Offer help, Warn, Enforce, Raise taxes [6,7]. It aims at increasing the effectiveness of antinicotine actions at the national and local level. This tool is also intended to help totally eliminate tobacco smoking, which constitutes one of the most widespread risk factors of many diseases. Effective implementation of the MPOWER package as a support to FCTC guarantees effective decrease in the use of tobacco products worldwide. However, a vast majority of worldwide population is not covered by MPOWER package [8].

From studies conducted by scientists with the greatest expertise in the field of health, performed in major research centers, it has become evident that passive smoking contributes greatly to increased frequency of various diseases, including many types of cancer and cardiovascular diseases [9-11]. Providing areas free from tobacco smoke helps protect health of the non-smokers, especially children, and contributes to lowering the frequency of smoking in the society [12]. Enforcing of total smoking ban in public places is a very important element of the anti-nicotine campaign. Providing areas where smoking is allowed (e.g., smoking rooms) contributes significantly to lowering the effectiveness of anti-tobacco regulations. Transferring the habit of non-smoking into the homes of the smokers is a characteristic phenomenon observed in the countries where a total ban on smoking in public places was introduced $[13,14]$. Introducing smoking ban in public places is widely supported by society; such conclusion is also supported by data from countries where tobacco smoking in public places is banned [7].

A common theory that a ban on tobacco smoking and other tobacco products will be costly for economy and for catering and entertainment industry in particular, is false. Results of more comprehensive research, on the other hand, show that the economic benefits resulting from elimination of tobacco smoke from the human environments are far higher than the profits harvested by the tobacco-producing, catering and entertainment sectors [15-18].

Effective enforcement of the smoking ban is an essential element in the fight with tobacco epidemics. The manner in which the owners of the buildings where the ban is disobeyed, as well as the people who commit such an offence are punished, is to be very precise and should be applied with great consistency.

Creating environments free from tobacco smoke is developing dynamically. More and more countries introduce a total smoking ban in public places as an effective and socially acceptable means to fight the epidemics of tobacco smoking [8,19-21].

Most Poles supported the introduction of total smoking ban in all places where non-smokers stay. Almost $84 \%$ of the non-smokers and close to $70 \%$ of the smokers declared their support for the ban [22]. On November 15, 2010, an act was passed amending the Act of 9 November 1995 on protection of health against the consequences of consumption of tobacco and tobacco products [23]. As a result of the amendment, smoking ban has been applied in many public places. This fact enables protection of the citizens from inhaling environmental tobacco smoke.

Total smoking ban (with no option to provide smoking rooms) is valid e.g., at health centers and schools. 
The smoking ban with the option to provide a smoking room is valid e.g., for catering venues, night clubs, culture centers and universities [23]. Prior to introducing the amendment to the Act, that is before November 15, 2010, any bans concerning smoking tobacco in public places in Poland were far less restrictive. In many places it was allowed to provide rooms for smokers, e.g., at catering centers. In public transport facilities, smoker compartments were provided. Local authorities had the right to indicate additional places that were covered by the ban (e.g., bus or tram stops).

The aim of this work was to evaluate the influence of the Act of 8 April 2010 on amendment of the Act on protection of health against the consequences of consumption of tobacco and tobacco products and Act on National Sanitary Inspectorate in Poland [23], which for example increased the number of places covered by the smoking ban, with particular reference to the influence of the 8 April 2010 Act, on the frequency of complying with the above listed bans by the students of Health Science Department at the Medical University of Lodz, Poland.

\section{MATERIAL AND METHODS}

Study was performed as part of the project "Health Department Free from Tobacco Smoke" realized by the Social Medicine Institute of the Medical University of Lodz in 2007-2011. During that period, a prospective study was carried out as well as an observation-analytical one among 2985 students, that is $96.6 \%$ of all 1st year students at the Health Department of the Medical University of Lodz.

While collecting empirical material, a random questionnaire survey was used comprising 22 questions. Smokers had to answer 40 questions in total. Additionally, they were also asked to answer 6 questions included in the Fagerström nicotine addiction test and 12 questions included in the Schneider Motivation Test. In order to check whether the respondents complied with the ban prohibiting smoking, they were asked whether they smoked only in the areas designated for that purpose or wherever they wanted to. The questionnaire had been previously included in the pilot study [24] where the responsiveness and understanding of the questions were assessed. The questionnaire survey was anonymous. Students were asked to fill up the questionnaire sheet of their own free will after their classes.

From a group of 2985 respondents taking part in the study, 1038 people were selected who reported to be active smokers at the time of the study. The answers provided by the students were then divided into 2 groups. The 1st one comprised 530 answers of individuals who were included in the survey before November 15, 2010, i.e., prior to the introduction of the Act of 8 April 2010 on amendment of the Act on protection of health against the consequences of consumption of tobacco and tobacco products and Act on National Sanitary Inspectorate [23]. The other group included 508 respondents who took part in the study in December 2010 and December 2011, i.e., after the amendment restricting the provisions concerning smoking tobacco in public places had been enacted. The level of addiction was assessed by the number of cigarettes smoked per day. Respondents who smoked 10 or more cigarettes per day were classified as heavy smokers.

Descriptive and analytical interference methods were applied to analyze the collected empirical material. Structure indices were calculated to describe the whole group of respondents and the selected subgroups according to their quality features. $\mathrm{Chi}^{2}$ test was applied to compare the frequency of particular varieties of features in the studied groups and subgroups, and also to test the relationships between the quality features. The power of the relationship was evaluated using Pearson's correlation coefficient. The level of statistical significance was set at $p<0.05$. The Bioethics Committee of the Medical University of Lodz approved the study design. 


\section{RESULTS}

Among 1038 tobacco smoking respondents, there were 718 women $(69.2 \%)$ and 320 men (30.8\%). The participants up to 20 years of age represented $34.9 \%(\mathrm{~N}=362)$, those between 21 and 25 years of age $-47.2 \%(\mathrm{~N}=490)$, and over 26 years of age $-17.1 \%(\mathrm{~N}=178)$ of the study group. Eight students did not answer the question concerning their date of birth.

In the study group of 530 subjects interviewed before November 15, 2010, 70.7\% (375 people) smoked cigarettes every day. Among 508 respondents after November 15, 2010, i.e., after the amendment had been introduced, the percentage of the daily smokers was $64.2 \%(\mathrm{~N}=326)$. Before the amendment was introduced, in a group of 530 students, $25.5 \%(\mathrm{~N}=135)$ had smoked 10 or more cigarettes per day (heavy smokers). Among 508 subjects interviewed after November 15, 2010, the proportion of heavy smokers was lower $(9.1 \%, \mathrm{~N}=46)$. While analysing the collected empirical material, it has become evident that in the group of 530 subjects interviewed before November 15, 2010, i.e., before the amendment to the Act was passed, the percentage of those claiming that they smoked wherever they wanted to, which meant they did not comply with the smoking ban, was $60.0 \%(\mathrm{~N}=318)$, whereas among the 508 respondents after November 15, 2010, i.e., after the amendment was enacted, the percentage was $62.2 \%(\mathrm{~N}=316)$. The difference of 2.2 of the percentage points to the detriment of the period after the amendment is statistically irrelevant: $\mathrm{Chi}^{2}=0.530, \mathrm{p}>0.05$.

In the group of women, there was no statistically significant difference in their tobacco smoking behavior in the designated areas before and after the introduction of the amendment $\left(\mathrm{Chi}^{2}=0.800, \mathrm{p}>0.05\right)$. A similar situation was observed among men $\left(\mathrm{Chi}^{2}=3.533, \mathrm{p}>0.05\right)$.

In the group of 300 women asked before November 15, 2010 whether they smoked only in the designated areas, $52.7 \%$ respondents $(\mathrm{N}=158)$ answered they smoked anywhere they wanted to. In the group of 230 men, a similar answer was obtained from $69.6 \%$ respondents $(\mathrm{N}=160)$. In the period prior to the introduction of the amendment to the Act, it were in fact men who reported non-compliance with the smoking ban as opposed to women $\left(\mathrm{Chi}^{2}=15.490, \mathrm{p}<0.001, \mathrm{C}=0.169\right)$.

After the The Act of 8 April 2010 on amendment of the Act on protection of health against the consequences of consumption of tobacco and tobacco products and Act on National Sanitary Inspectorate [23] was introduced on November 15, 2010, in a group of 418 female respondents, $49.3 \%(\mathrm{~N}=206)$ claimed they smoked anywhere they wanted to. Among 90 men, 72 respondents provided a similar answer. Differences in frequency of the given answers, indicative of non-compliance with the smoking ban between the group of women and men, are statistically relevant: $\mathrm{Chi}^{2}=28.202, \mathrm{p}<0.001, \mathrm{C}=0.229$ (Table 1). While analyzing according to the age of the respondents the reported frequency of complying with the smoking ban before and after the amendment to the Act was introduced, it has been found that prior to the introduction of the amendment, the highest percentage of those smoking only in designated areas was recorded in the group of respondents who were over 25 years of age (49.2\%) and the lowest $(37.3 \%)$ in the group of those who were up to 20 . The observed difference is not statistically relevant.

After the amendment had been introduced, respondents at the age of 26 and above complied with the smoking ban considerably more frequently than their younger fellow students $\left(\mathrm{Chi}^{2}=14.386, \mathrm{p}<0.001, \mathrm{C}=0.166\right)$. When comparing the frequency of complying with the smoking ban before and after the introduction of the amendment in each of the 3 age groups, the observed differences were not statistically relevant. In the group of respondents up to 20 years of age: $\mathrm{Chi}^{2}=0.505, \mathrm{p}>0.05$, among those 21-25 years of age: $\mathrm{Chi}^{2}=0.001, \mathrm{p}>0.05$ and in a group of respondents over 25 years of age: $\mathrm{Chi}^{2}=2.071$, p $>0.05$ (Table 1). 
Table 1. Reported (non)compliance with the smoking ban by students before and after the amendment to the Act* was introduced according to sex and age

\begin{tabular}{|c|c|c|c|c|c|c|c|c|c|c|}
\hline \multirow{3}{*}{ Smoking places } & \multicolumn{4}{|c|}{$\begin{array}{l}\text { Gender } \\
{[\mathrm{n}(\%)]}\end{array}$} & \multicolumn{6}{|c|}{$\begin{array}{c}\text { Age } \\
\text { [years] }\end{array}$} \\
\hline & \multicolumn{2}{|c|}{ female } & \multicolumn{2}{|c|}{ male } & \multicolumn{2}{|c|}{$\leq 20$} & \multicolumn{2}{|c|}{$21-25$} & \multicolumn{2}{|c|}{$\geq 26$} \\
\hline & before & after & before & after & before & after & before & after & before & after \\
\hline $\begin{array}{l}\text { Smoked in } \\
\text { designated } \\
\text { places }\end{array}$ & $142(47.3)$ & $212(50.7)$ & $70(30.4)$ & $18(20.0)$ & $63(37.3)$ & $79(40.9)$ & $119(40.3)$ & $79(40.5)$ & $29(49.2)$ & $72(60.5)$ \\
\hline $\begin{array}{l}\text { Smoked } \\
\text { wherever they } \\
\text { wanted to }\end{array}$ & $158(52.7)$ & $206(49.3)$ & $160(69.6)$ & $72(80.0)$ & $106(62.7)$ & $114(59.1)$ & $176(59.7)$ & $116(59.5)$ & $30(50.8)$ & $47(39.5)$ \\
\hline \multirow[t]{2}{*}{ Total } & $300(100)$ & $418(100)$ & $230(100)$ & $90(100)$ & $169(100)$ & $193(100)$ & $295(100)$ & $195(100)$ & $59(100)$ & $119(100)$ \\
\hline & \multicolumn{2}{|c|}{$\begin{array}{c}\mathrm{Chi}^{2}=0.800 \\
\mathrm{p}>0.05\end{array}$} & \multicolumn{2}{|c|}{$\begin{array}{c}\mathrm{Chi}^{2}=3.533 \\
\mathrm{p}>0.05\end{array}$} & \multicolumn{2}{|c|}{$\begin{array}{c}\mathrm{Chi}^{2}=0.505 \\
\mathrm{p}>0.05\end{array}$} & \multicolumn{2}{|c|}{$\begin{array}{c}\mathrm{Chi}^{2}=0.001 \\
\mathrm{p}>0.05\end{array}$} & \multicolumn{2}{|c|}{$\begin{array}{c}\mathrm{Chi}^{2}=2.071 \\
\mathrm{p}>0.05\end{array}$} \\
\hline
\end{tabular}

* The Act of 8 April 2010 on amendment of the Act on protection of health against the consequences of consumption of tobacco and tobacco products and Act on National Sanitary Inspectorate [23].

Before - before the amendment to the Act; after - after the amendment to the Act.

$\mathrm{Chi}^{2}$ - Chi-square test.

Among 1038 respondents smoking tobacco during the study, the majority, i.e., $67.5 \%(\mathrm{~N}=701)$ smoked every day. After November 15, 2010, in the group of the daily smokers, the percentage of respondents declaring smoking anywhere they wanted to fell by $0.7 \%$ percentage points as opposed to the period prior to the introduction of the amendment (58.7\% vs. 58\%). The observed difference was statistically irrelevant $\left(\mathrm{Chi}^{2}=0.34, \mathrm{p}>0.05\right)$.

Among people smoking occasionally after the introduction of the amendment, the percentage of those declaring non-compliance with the smoking ban was lower by $14.3 \%$ percentage points as opposed to the period before November 15, 2010 (63.2\% vs. 48.9\%). The difference is statistically relevant: $\mathrm{Chi}^{2}=6.955, \mathrm{p}<0.01, \mathrm{C}=0.142$ (Table 2). Students smoking occasionally before November 15, 2010, reported non-compliance with the smoking ban more often in comparison with the respondents smoking daily. However, the difference was statistically irrelevant $\left(\mathrm{Chi}^{2}=0.950\right.$, $\mathrm{p}>0.05$ ). The situation was altered after the new regulations had been introduced as of November 15, 2010. Daily smokers reported non-compliance with the smoking ban more frequently than the respondents smoking occasionally ( $48.9 \%$ vs. $58 \%$ ). The difference is statistically relevant $\left(\mathrm{Chi}^{2}=3.882, \mathrm{p}<0.05, \mathrm{C}=0.087\right)($ Table 2$)$.

\section{DISCUSSION}

Despite the great support among the Poles in favor of the introduction of the smoking ban in public places, a high percentage of people endangered with inhaling tobacco smoke in places where smoking is prohibited may be observed. This results from the fact of not complying with the smoking ban by smokers, which is caused by irresponsibility, insufficient monitoring and ineffective legal enforcement system.

As can be seen from the study carried out in Poland that was commissioned by the Main Sanitary Inspectorate in December 2011 (a year after introducing the amendment), every 3rd smoking man and every 5th smoking woman were exposed to passive smoking in bars and pubs. Exposure of the non-smokers was lower: $19 \%$ and $13 \%$ respectively [25]. According to the legal regulations that were in power in Poland at that time, the non-smokers ought to be totally protected 
Table 2. Reported (non)compliance with the smoking ban by students before and after the introduction of the amendment to the Act* according to the frequency of smoking tobacco

\begin{tabular}{|c|c|c|c|c|}
\hline \multirow[t]{2}{*}{ Smoking places } & \multicolumn{2}{|c|}{$\begin{array}{c}\text { Smoked occasionally } \\
{[\mathrm{n}(\%)]}\end{array}$} & \multicolumn{2}{|c|}{$\begin{array}{l}\text { Smoked daily } \\
{[\mathrm{n}(\%)]}\end{array}$} \\
\hline & before & after & before & after \\
\hline $\begin{array}{l}\text { Smoked only in } \\
\text { designated places }\end{array}$ & $57(36.8)$ & $93(51.1)$ & $155(41.3)$ & $137(42.0)$ \\
\hline $\begin{array}{l}\text { Smoked wherever they } \\
\text { wanted to }\end{array}$ & $98(63.2)$ & $89(48.9)$ & $220(58.7)$ & $189(58.0)$ \\
\hline \multirow[t]{2}{*}{ Total } & $155(100)$ & $182(100)$ & $375(100)$ & $326(100)$ \\
\hline & \multicolumn{2}{|c|}{$\begin{array}{c}\mathrm{Chi}^{2}=6.955 \\
\mathrm{p}<0.01 \\
\mathrm{C}=0.142\end{array}$} & \multicolumn{2}{|c|}{$\begin{array}{c}\mathrm{Chi}^{2}=0.34 \\
\mathrm{p}>0.05\end{array}$} \\
\hline
\end{tabular}

* The Act of 8 April 2010 on amendment of the Act on protection of health against the consequences of consumption of tobacco and tobacco products and Act on National Sanitary Inspectorate [23].

C- C-Pearson's correlation coefficient.

Other abbreviations as in Table 1.

against inhaling tobacco smoke. With high frequency of noncompliance with the smoking ban, few people faced penalties resulting from such behavior. Only a small percentage of Poles were penalized with fines for smoking in not designated areas or were a witness to such a situation: $8 \%$ male smokers, $9 \%$ female smokers, $8 \%$ non-smoking males and $4 \%$ non-smoking females, respectively [25].

According to other authors, heavy smokers are more likely to represent older age groups [26]. As the vast majority of the study population were people under 26 , the level of addiction was assessed only by the number of cigarettes smoked per day. Respondents who smoked 10 or more cigarettes per day were classified as heavy smokers. The study is not following the same sample of people but comparing 2 different samples before and after the Act. This can have the impact on study results. Comparison of the 2 groups in terms of the proportion of daily smokers and occasional smokers differed in statistically relevant way $(\mathrm{p}<0.03)$. Comparison of the 2 groups in terms of the level of addiction was statistically significant ( $p<0.001$ ). Percentage of heavy smokers and daily smokers was higher among the participants interviewed before the Act of 8 April 2010 on amendment of the Act on protection of health against the consequences of consumption of tobacco and tobacco products and Act on National Sanitary Inspectorate [23] was introduced on November 15, 2010. The data obtained in this study is valid only for the students of Health Department at the Medical University of Lodz. It cannot be generalized to all students of the University or in Poland as it is not a representative sample. Only the students beginning their studies at the 1st years of medical majors were interviewed. Behavior connected with the health of the studied group may differ from the behavior of students beginning their studies at departments that are not closely related to the studies of human health. It seems reasonable to believe that frequency of non-compliance with smoking bans at other departments may be even higher. As to the question concerning smoking only in the designated areas, the percentage of people claiming they smoked wherever they wanted to and not complying with the smoking ban before the introduction of the Act was $60 \%$ (318 people) and after the Act was introduced, it was $62.2 \%$ (316 people); that means it was higher by 2.2 percentage points. 
High percentage of students beginning their studies in the 1st years and declaring in this study non-compliance with the smoking ban is alarming. Of particular concern is the fact that respondents are people studying subjects related to medicine. Most of them will in the future find employment in health care facilities and health protection centers. They will be responsible for promoting health and they will have great influence on the development of legislation in the field of health protection.

Studies carried out by other authors point to the great differentiation in the percentage of smokers declaring their compliance with the smoking ban.

In the studies of Chaaya et al., among 545 students of a private university in Lebanon, the percentage of people complying with the smoking ban introduced at the university was high. Over $70 \%$ of the respondents reported smoking only in the designated areas. Contrary to the results presented in this work, in Chaaya's studies there were no significant differences observed in compliance with the smoking ban between women and men [27].

In a work by Lazarus et al., among 229 students in the northern Greece, majority reported non-compliance with the smoking ban by smoking in every place they wanted to and where it was forbidden [28].

The analysis carried out by Yong et al. on the basis of International Tobacco Control Southeast Asia Survey results showed that the reported compliance with the smoking ban in Malaysia was very high, i.e., 95\%, whereas in Thailand this percentage was significantly lower, 51\% [28].

In the study carried out by Raver et al. among taxi drivers in Lisbon after the introduction of smoking ban in taxies, $66.1 \%$ of the smoking drivers declared that they smoked in their cars. In the examined group, none of the drivers was penalized with a fine for non-compliance with the smoking ban [30].

It is difficult to define clearly the main reason for noncompliance with the smoking ban. Many factors contribute to this phenomenon. As can be seen from many studies, a vast majority of those not complying with the regulations have never been punished for this, which points to the low level of law enforcement.

Also of importance is the fact that smokers often do not have sufficient knowledge about the harmful influence of environmental tobacco smoke on the non-smoker organism. There are many citizens in Poland who perceived these new, more rigorous regulations as an attack on their personal freedom; an attitude like that might be due also to insufficient information provided to the society on the major advantages of the implemented changes.

Introducing new legislation ought to be supported by additional intervention programs which would encourage and support the smokers in complying with new regulations and limit the number of smoked cigarettes or eventually quit the smoking habit. Studies by Harrius et al. showed that intervention programs that encourage to comply with the smoking ban significantly increase the percentage of people abiding the law [31].

The present study, carried out in Poland among students who began their studies after the amendment was introduced on November 15, 2010, was done after 1 month and after 1 year of introducing the more rigorous antinicotine regulations. As can be seen from the studies of other authors, declaring compliance with the smoking ban in public places increases with the duration of those provisions [32]. This may suggest that also in Poland we will observe this positive trend.

\section{CONCLUSIONS}

The Act of 8 April 2010 on amendment of the Act on protection of health against the consequences of consumption of tobacco and tobacco products and Act on National Sanitary Inspectorate [23] in Poland did not cause the expected changes in the frequency of complying with the smoking ban by the students beginning their 1st year of studies.

The major issue of non-compliance with the smoking ban by men in comparison with women and by 
the younger people in comparison with the students at the age of 26 and more, and by the students smoking daily as opposed to those smoking occasionally implies the necessity to take preventive measures targeted at the listed groups of academic youths.

In order to achieve the expected effectiveness of the provisions of the Act that regulates problems connected with smoking in Poland, it is necessary to undertake additional and multifaceted measures to publicize current law and then inflict serious penalties on those who do not comply with its provisions.

\section{REFERENCES}

1. World Health Organization. Report on the global tobacco epidemic. Warning about the dangers of tobacco. Geneva: World Health Organization; 2011.

2. Zatoński W, Przewoźniak K. [Smoking in the adult population in Poland in the years 1974-1995]. In: Zatoński W, Przewoźniak K, editors. [Smoking in Poland: Attitudes, health consequences and prevention]. Warszawa: Centrum Onkologii - Instytut: 1999. p. 85-93. Polish.

3. Kaleta D, Kozieł A, Miśkiewicz P. [Global Adult Tobacco Survey in Poland - The aim and current experiences]. Med Pr. 2009;60(3):197-200. Polish.

4. [Global Adult Tobacco Survey. Poland 2009-2010]. Warszawa: Ministerstwo Zdrowia; 2010 [cited 2012 July 23]. Availablefrom:http:/www2.mz.gov.pl/wwwfiles/ma_struktura/docs/ sondaz_tyt_15112010.pdf. Polish.

5. WHO Framework Convention on Tobacco Control. Geneva: World Health Organization; 2003 [cited 2014 Apr 17]. Available from: http://whqlibdoc.who.int/publications/2003/9241591013.pdf.

6. Kaleta D, Kozieł A, Miśkiewicz P. [MPOWER - Strategy for fighting global tobacco epidemic]. Med Pr. 2009;60(2):145-9. Polish.

7. World Health Organization. WHO Report on the global tobacco epidemic, 2008 - The MPOWER package. Geneva: WHO; 2009.
8. World Health Organization. Report on the global tobacco epidemic. Implementing smoke-free environments. Geneva: WHO; 2009.

9. Scientific Committee on Tobacco and Health. Update of evidence on health effects of secondhand smoke. London: Scientific Committee on Tobacco and Health; 2004 [cited 2012 Apr 30]. Available from:http://www.who.int/tobacco/ mpower/en_tfi_scientiifc_committee_dh.pdf.

10. U.S. Department of Health and Human Services. The health consequences of involuntary exposure to tobacco smoke: A report of the Surgeon General. Atlanta: U.S. Department of Health and Human Services, Centers for Disease Control and Prevention, Coordinating Center for Health Promotion, National Center for Chronic Disease Prevention and Health Promotion, Office on Smoking and Health; 2006 [cited 2013 July 23]. Available from: http://www.ncbi.nlm.nih.gov/books/ NBK44324/pdf/TOC.pdf.

11. International Agency for Research on Cancer. Tobacco smoke and involuntary smoking: Summary of data reported and evaluation. Volume 83. IARC monographs on the evaluation of carcinogenic risks to humans. Geneva: IARC; 2004.

12. Zablocki RW, Edland SD, Myers MG, Strong DR, Hofstetter CR, Al-Delaimy WK. Smoking ban policies and their influence on smoking behaviors among current California smokers: A population-based study. Prev Med. 2014;59: 73-8, http://dx.doi.org/10.1016/j.ypmed.2013.11.018.

13. Borland RM, Yong HH, Cummings KM, Hyland A, Anderson S, Fong GT. Determinants and consequences of smokefree homes: Findings from the International Tobacco Control (ITC) Four Country Survey. Tob Control. 2006;15(Suppl 3):42-50, http://dx.doi.org/10.1136/tc.2005.012492.

14. Guzmán A, Walsh MC, Smith SS, Malecki KC, Nieto FJ. Evaluating effects of statewide smoking regulations on smoking behaviors among participants in the Survey of the Health of Wisconsin. WMJ. 2012;111(4):166-71.

15. International Agency for Research on Cancer. Evaluating the effectiveness of smoke-free policies. Volume 13. IARC Handbooks of Cancer Prevention. Lyon: IARC; 2009 [cited 
2013 Jul 22]. Available from: http://www.iarc.fr/en/publications/pdfs-online/prev/handbook13/handbook13-0.pdf.

16. Howell F. Smoke-free bars in Ireland: A runaway success. Tob Control. 2005;14(2):73-4, http://dx.doi.org/10.1136/ tc.2005.011304.

17. Scollo M, Lal A, Hyland A, Glantz S. Review of the quality of studies on the economic effects of smoke-free policies on the hospitality industry. Tob Control. 2003;12(1):13-20, http://dx.doi.org/10.1136/tc.12.1.13.

18. Siegel M. Economic impact of $100 \%$ smoke-free restaurant ordinances. In: Smoking and restaurants: A guide for policy-makers. Berkeley: UC Berkeley/UCSF Preventative Medicine Residency Program, American Heart Association, California Affiliate Alameda County Health Care Services Agency, Tobacco Control Programme; 1992. p. 26-30.

19. El Ansari W, Stock C. Factors associated with smoking, quit attempts and attitudes towards total smoking bans at university: A survey of seven universities in England, Wales and Northern Ireland. Asian Pac J Cancer Prev. 2012;13(2): 705-14, http://dx.doi.org/10.7314/APJCP.2012.13.2.705.

20. Lechner WV, Meier E, Miller MB, Wiener JL, Fils-Aime Y. Changes in smoking prevalence, attitudes, and beliefs over 4 years following a campus-wide anti-tobacco intervention. J Am Coll Health. 2012;60(7):505-11, http://dx.doi.org/ 10.1080/07448481.2012.681816.

21. Lee JG, Goldstein AO, Klein EG, Ranney LM, Carver AM. Assessment of college and university campus tobacco-free policies in North Carolina. J Am Coll Health. 2012;60(7):512-9, http://dx.doi.org/10.1080/07448481.2012. 690464.

22. Chief Sanitary Inspectorate. [Report of a nationwide survey on attitudes towards smoking]. Warszawa; February 2011 [cited 2013 Jul 15]. Available from: http:// www.gis.gov.pl/ckfinder/userfiles/files/PZ/Raport\%20 og\%C3\%B3lnopolski\%20\%202011.pdf. Polish.

23. [The Act of 9 November 1995 on protection of health against the consequences of consumption of tobacco and tobacco products. J Laws. 1996, No. 10, item 55, with later amendment The Act of 8 April 2010 on amendment of the Act on protection of health against the consequences of consumption of tobacco and tobacco products and Act on National Sanitary Inspectorate]. J Laws 2010 No 81 item 529. Polish.

24. Kowalska A, Rzeźnicki A, Drygas W. [Attitudes and behaviour concerning cigarette smoking among the students of the first year at the Health Department]. Przegl Lek. 2006;63(10):1041-4. Polish.

25. Chief Sanitary Inspectorate. [Report of a nationwide survey on attitudes towards smoking]. Warszawa; December 2011 [cited 2013 July 20]. Available from: http://www.gis.gov.pl/ ckfinder/userfiles/files/PZ/Materia\%C5\%82y\%20PT/raport_palenie_2011_TOB3CIT.pdf. Polish.

26. Kaleta D, Makowiec-Dąbrowska T, Dziankowska-Zaborszczyk E, Fronczak A. Determinants of heavy smoking: Results from the global adult tobacco survey in Poland (2009-2010). Int J Occup Med Environ Health. 2012;25(1):66-79, http:// dx.doi.org/10.2478/s13382-012-0009-7.

27. Chaaya M, Alameddine M, Nakkash R, Afifi RA, Khalil J, Nahhas G. Students' attitude and smoking behaviour following the implementation of a university smoke-free policy: A cross-sectional study. BMJ Open. 2013;3(4):e002100, http://dx.doi.org/10.1136/bmjopen-2012-002100.

28. Lazuras L, Eiser JR, Rodafinos A. Predicting smokers' non-compliance with smoking restrictions in public places. Tob Control. 2009;18(2):127-31, http://dx.doi.org/10.1136/ tc.2008.025841.

29. Yong HH, Foong K, Borland R, Omar M, Hamann S, Sirirassamee B, et al. Support for and reported compliance among smokers with smoke-free policies in air-conditioned hospitality venues in Malaysia and Thailand: Findings from the International Tobacco Control Southeast Asia Survey. Asia Pac J Public Health. 2010;22(1):98-109, http://dx.doi. org $/ 10.1177 / 1010539509351303$.

30. Ravara SB, Castelo-Branco M, Aguiar P, Calheiros JM. Compliance and enforcement of a partial smoking ban in Lisbon taxis: An exploratory cross-sectional study. 
BMC Public Health. 2013;13:134, http://dx.doi.org/10.1186/ 1471-2458-13-134.

31. Harris KJ, Stearns JN, Kovach RG, Harrar SW. Enforcing an outdoor smoking ban on a college campus: Effects of a multicomponent approach. J Am Coll Health. 2009;58(2):

121-6, http://dx.doi.org/10.1080/07448480903221285.
32. Trinidad DR, Gilpin EA, Pierce JP. Compliance and support for smoke-free school policies. Health Educ Res. 2005;20(4):466-75, http://dx.doi.org/10.1093/her/cyg143.

This work is available in Open Access model and licensed under a Creative Commons Attribution-NonCommercial 3.0 Poland License - http://creativecommons.org/ licenses/by-nc/3.0/pl/deed.en. 